\title{
sciendo
}

\section{Economic analysis of rice production by small-holder women farmers in Adamawa State, Nigeria}

\author{
Adewuyi Adekunle Kolawole \\ Department of Agricultural Technology, Federal Polytechnic, Mubi, \\ Adamawa State, Nigeria \\ kolbetsy@yahoo.com
}

Amurtiya Michael

Department of Agricultural Economics and Extension, Modibbo Adama University of Technology, Yola, Adamawa State, Nigeria

michaelamurtiya@yahoo.com

\begin{abstract}
This study is focused on analysing the economics of rice production by the smallholder female rice-farmers in Adamawa State, Nigeria. Specifically, the study described female rice-farmers' socio-economic characteristics, analysed their technical and allocative efficiencies, and also assessed their economic efficiency in the area. Primary data were collected from 180 randomly selected female ricefarmers in Adamawa State using a semi-structured questionnaire. Descriptive statistics and stochastic frontier function were used analysing the data collected. Findings of the study revealed that the technical in-efficiency of the farmers is influenced by farming experience, education, and access to credit facilities. Also, the allocative in-efficiency of female farmers was influenced by education, household size, and access to credits. The result showed that education and access to credit facilities were common factors affecting the technical and allocative efficiency of female rice farmers in the area. The mean economic efficiency of the female farmers was 0.6. Therefore, the study recommends that the government and other actors in the agricultural sector should facilitate women's access to credit facilities and other agricultural information relevant to rice production.
\end{abstract}

Keywords: Adamawa state, efficiency, Nigeria, rice production, women.

JEL classification: Q12, Q18.

DOI: 10.2478/crebss-2021-0001

Received: October 09, 2020

Accepted: November 27, 2020

\section{Introduction}

Rice is Nigeria's most popular food crop which has remained a key component of most households' diet across various parts of the country (National Bureau of Statistics, 2014). This has made the crop a topical issue in political discussions on food 
security in the country (Erenstein et al., 2003). However, the nation's rice production has fallen short of its demand leading to increased importation of the commodity. This has made the country become one of the leading importers of the commodity in the West African sub-region (Kagbu et al., 2016; Iwuchukwu, Udegbunam, 2017). This trade imbalance will continue to affect the nation's economy negatively unless the production of the commodity is increased.

In response to the prevailing rice supply deficit situation in the country, successive governments over the years have intervened in the rice sub-sector through the introduction of some policies and programmes aimed at boosting local production of the commodity by farmers (Badawi, 2004). One of such initiatives in recent years is the adoption of rice crop under the Federal Government's Agricultural Transformation Agenda. The policy targeted the production of four main crops (cassava, rice, sorghum, and cotton) through which about 3.5 million jobs will be created annually. It is expected that at every node of the value chains of these crops, people will be economically empowered when fully implemented (Osabuohien et al., 2018).

Across the Sub-Saharan African region, agriculture is mostly viewed as a gendered occupation due to the differentiated roles being played by males and females (Angya, 2008). Due to these differentiated roles, male and female farmers mostly access productive resources differently. In most contexts, women have huge limitations (due to cultural and religious factors) in undertaking farming activities. Despite the challenges women face, they still play prominent roles in agricultural activities. For instance, they supply most of the needed labour in agricultural activities and this is the most important factor of production to farmers, as it is needed at every stage of agricultural production (Kagbu et al., 2016; Iwuchukwu, Udegbunam, 2017).

Addressing the continuing decline in local food production will entail acknowledging the contributions of the various intra-household units in the overall production outputs (Ismaila et al., 2010). The separate roles of men and women in the development of agriculture must be critically identified to achieve a meaningful impact on food production in the country (United Nations Development Programmes, 2010). Therefore, efforts geared towards increasing local rice production in Nigeria should give prominence to the different roles played by men and women in agricultural activities (Effiong et al., 2015). Across various parts of Nigeria, women play diverse roles in rice production, depending on location and prevailing socio-cultural factors. Consequently, this study analysed the economics of rice production by female rice-farmers in Adamawa State, Nigeria. The specific objectives of the study were to:

i. describe the socio-economic characteristics of female rice-farmers in the area,

ii. analyse the technical efficiency of the female rice farmers,

iii. examine the allocative efficiency of female rice farmers,

iv. assess the economic efficiency of the female rice farmers in the area.

\section{Literature Review}

Rice is a major staple food crop that is consumed across all parts of Nigeria. The demand for rice in the country had been soaring and the rising demand was partly as a result of increased income levels, rapid urbanization, and the associated change in occupational structure (Akande, 2002). Moses and Adebayo (2007) asserted that per capita annual rice consumption level in the country increased by about $7.3 \%$ over the years. Due to the ever-increasing demand for the commodity 
across the country, rice has now transformed into a cash crop, especially in areas where the crop is produced. The activities involved in rice production contribute immensely to creating employment opportunities in the communities concerned (Daranola, 2005). As of 2012, the country imported about 2.8 million tonnes, which is a geometric increase from the 2007 total imports, which was about 1.7 million metric tonnes (FAO, 2013).

Nigeria has great potential to produce rice in both the dry and rainy seasons. It is estimated that the country has a cultivable land size of about 82 million hectares, with about 4.6 million hectares being utilized for paddy cultivation. Similarly, only 50,000 hectares were being for irrigation out of the 3.14 million hectares of irrigable land suitable for rice irrigation (Kura, 2009). Rice production in Nigeria is dominated by smallholder farmers who cultivate small hectares of land using the traditional method of farming; yields are low and hence the wide gap of demand and supply (Ibrahim, 2014). Dia et al. (2009) emphasized that the pace of agricultural development in the country is closely related to the factors which affect the productivity of women labour.

Efficient utilisation of resources by farmers is central to increasing production which can contribute to economic growth. Resource use efficiency could be technical, economic, or allocative (Farell, 1957; Farell, 1957). Technical efficiency depends on the relationship between input and output, while technical efficiency considers the maximum potentials (Fan, 1999). The stochastic frontier production function is commonly used to assess resource use efficiency using maximum likelihood procedures (Ogundari, Ojo, 2006). The method is asymptotically better than other estimators (Coelli, 1995; Yao, Liu, 1998). In assessing efficiency, efficiency entails the ability of the farmer's actual production point to lie on the frontier, while being below the frontier suggests technical inefficiency (Okoruwa, Ogundele, 2008). Similarly, economic efficiency depends on both technical and allocative efficiencies (Ogundari, Ojo, 2006; Kalirajan, Shand, 1999).

\section{Research Methodology Study Area}

The study was carried out in Adamawa State, North-East, Nigeria. According to Adebayo and Tukur (1999), the State is located along latitude 70 and $11^{0}$ North, and longitude $11^{\circ}$ and $14^{\circ}$ East. Adamawa State has a land area of about $38,741 \mathrm{Km}^{2}$, and a population of $3,178,950$ people comprising of $1,607,270$ males and 1,571,680 females (National Population Commission, 2006). The predominant occupations in the state are crop farming and livestock herding.

\section{Sample and Data Collection}

The study adopted a multi-stage sampling technique to collect data for the study. Three Local Government Areas (namely; Mubi North, Furore, and Lamurde) were purposively selected based on their high involvement in rice cultivation in Adamawa State in the first stage. In the second stage, 17 wards were proportionately selected from the selected Local Government Areas. In the third stage, one female rice farmers' association was randomly selected (using random numbers) from each of the 17 wards. In the last stage, a systematic random sampling technique was used to select 180 female farmers from the selected female farmers' groups in the selected area. 


\section{Data Analysis}

In the analysis of the data collected, both descriptive and inferential statistics were used. The socio-economic characteristics of the respondents were described using descriptive statistics (specifically, frequency distribution, means, and percentages). Following Muhammad-Lawal et al. (2009), a stochastic frontier model of CobbDouglas functional was adopted to assess the resource use efficiency of the respondents. According to Sheikh (2006), the stochastic frontier production function approach appears to be appropriate for assessing technical and allocative efficiency in rice production, given the inherently stochastic nature of rice production. The functional form was used because it meets the requirement of being self-dual, thereby permitting the assessment of economic efficiency (Kopp, Smith, 1980; Yao and Liu, 1998). The model is specified as:

$$
\mathrm{LnY}=\beta_{0}+\beta_{1} \operatorname{LnX}_{1}+\beta_{2} \operatorname{LnX}_{2}+\beta_{3} \operatorname{LnX}_{3}+\beta_{4} \operatorname{LnX}_{4}+\beta_{5} \operatorname{LnX}_{5}+\beta_{6} \operatorname{LnX}_{6}+\mathrm{v}_{\mathrm{i}}-\mathrm{u}_{\mathrm{i}}
$$

where $Y=$ Output of rice in $\mathrm{kg}, X_{1}=$ Farm size (ha), $X_{2}=$ Seed in $\mathrm{kg}, X_{3}=$ Fertilizer in $\mathrm{kg}$, $X_{4}=$ Hired labour in man-days, $X_{5}=$ Family labour in man-days, $X_{6}=$ Herbicides in litres.

It is assumed that the technical efficiency effects are independently distributed (Aigner et al., 1977) and $U_{i}$ arises by truncation (at zero) of the normal distribution with mean, $\mathrm{U}_{\mathrm{ij}}$, and variance $\partial^{2}$, where $\mathrm{U}_{\mathrm{ij}}$ is defined by:

$$
u_{i}=\partial_{0}+\partial_{1} Z_{1}+\partial_{2} Z_{2}+\partial_{3} Z_{3}+\partial_{4} Z_{4}+\partial_{5} Z_{5}+\partial_{6} Z_{6}
$$

where $U_{i}=$ Technical inefficiency of the $i^{\text {th }}$ farmer, $z_{1}=$ Age of the farmer (years), $z_{2}=$ Access to education (Dummy), $z_{3}=$ Farming experience (years), $z_{4}=$ Household size (number), $Z_{5}=$ Access to Extension Services (Dummy: 1 for Yes and 0 otherwise), $Z_{6}=$ Access to credit facilities (Dummy: 1 Yes, and 0 otherwise), $\partial=$ a vector of unknown parameters to be estimated.

The stochastic frontier cost function is used in estimating the allocative efficiency of resource-use female rice farmers in the study area. The model is specified as:

$$
\mathrm{C}_{\mathrm{i}}=\mathrm{g}\left(\mathrm{P}_{\mathrm{i} \beta}\right)+\left(\mathrm{v}_{\mathrm{i}}-\mathrm{u}_{\mathrm{i}}\right)
$$

Where $C_{i}=$ the total production cost of $i^{\text {th }}$ farmer, $P_{i}=$ a vector of variable input price used by the $i^{\text {th }}$ farmer, $g=$ a suitable functional form such as the Cobb-Douglas function, $\beta=$ the parameter to be estimated, $v_{i}=$ the symmetric component which represents a random disturbance, cost due to factors outside the control of the farmers, $U_{i}=$ the one-sided disturbance term used to represent allocative inefficiency, $v_{i}$ is independent of $v_{i}$. The cost-efficiency of an individual farmer is defined in terms of the ratio of observed cost $\left(\mathrm{C}^{\circ}\right)$ to the corresponding minimum cost $\left(\mathrm{Cm}^{\mathrm{m}}\right)$ given the available technology.

$$
\text { Cost efficiency }\left(\mathrm{C}_{\mathrm{E}}\right)=\frac{C^{0}}{C^{m}}=\frac{g\left(P_{i}, Y_{i}, \beta\right)+\left(V_{i}-U_{i}\right)}{g\left(P_{i}, Y_{i}, \beta\right)}=\exp \left(U_{i}\right)
$$

where $\mathrm{C}^{\circ}=$ the observed cost and represents the actual total production cost, $\mathrm{C}^{\mathrm{m}}=$ the minimum cost and represents the frontier total production cost or least total production level.

The explicit Cobb Douglas functional form for rice farmers in the study area is specified as follows:

$$
\operatorname{lnC}=\alpha_{0}+\alpha_{1} \ln \mathrm{P}_{1}+\alpha_{2} \ln \mathrm{P}_{2}+\alpha_{3} \ln \mathrm{P}_{3}+\alpha_{4} \ln _{4}+\alpha_{5} \ln \mathrm{P}_{5}+\alpha_{6} \ln \mathrm{P}_{6}+\alpha_{7}+\left(\mathrm{v}_{\mathrm{i}}-\mathrm{u}_{\mathrm{i}}\right)
$$


where $C=$ total cost of rice production ( $\mathrm{N}$ ), $\mathrm{P}_{1}=$ cost of fertilizer $(\mathrm{N}), \mathrm{P}_{2}=$ cost of seed (\#), $\mathrm{P}_{3}=$ cost of transportation ( $\left.\mathrm{N}\right), \mathrm{P}_{4}=$ cost of labour ( $\left.\mathrm{N}\right), \mathrm{P}_{5}=$ cost of herbicides (N), $\mathrm{P}_{6}=$ expenses on land ( $), a=$ parameter to be estimated. Subscript ij means $j^{\text {th }}$ observation of $i^{\text {th }}$ farmer.

There is a general assumption that cost inefficiency effects are independently distributed and $v_{i}$ arises by truncation (at zero) of the normal distribution with mean, $\mathrm{U}_{\mathrm{ij}}$, and variance $\partial^{2}$, where $\mathrm{U}_{\mathrm{ij}}$ is defined by:

$$
\mathrm{u}_{\mathrm{i}}=\partial_{0}+\partial_{1} \mathrm{Z}_{1}+\partial_{2} \mathrm{Z}_{2}+\partial_{3} \mathrm{Z}_{3}+\partial_{4} \mathrm{Z}_{4}+\partial_{5} \mathrm{Z}_{5}+\partial_{6} \mathrm{Z}_{6}
$$

where $u_{i}=$ The cost inefficiency of the $i^{\text {th }}$ farmer, $z_{1}=$ Age of the farmer (years), $z_{2}=$ Access to education (Dummy), $Z_{3}=$ Farming experience (years), $Z_{4}=$ Household size (number), $Z_{5}=$ Access to Extension Services (Dummy: 1 for Yes and 0 otherwise), $Z_{6}=$ Access to credit facilities (Dummy: 1 Yes, and 0 otherwise), $\partial=a$ vector of unknown parameters to be estimated. Economic efficiency is a product of both technical and allocative efficiencies. Therefore, Economic efficiency $\left(\mathrm{E}_{\mathrm{E}}\right)=(\mathrm{TE})$. ( $\left.\mathrm{C}_{\mathrm{E}}\right)$.

\section{Results and Discussion Socio-economic Characteristics of Female Farmers}

The result in Table 1 showed that the mean age of the female farmers was about 36years. This finding suggests that the majority of the respondents were within their economically active age.

Table 1 Socio-economic Characteristics of Female Rice Farmers

\begin{tabular}{|c|c|c|}
\hline Variable & Frequency & Percentage (\%) \\
\hline \multicolumn{3}{|l|}{ Age } \\
\hline$\leq 30$ & 54 & 30.00 \\
\hline $31-40$ & 76 & 42.22 \\
\hline $41-50$ & 35 & 19.44 \\
\hline $51-60$ & 12 & 06.67 \\
\hline 60 and above & 03 & 01.67 \\
\hline Mean & 36.42 & \\
\hline \multicolumn{3}{|l|}{ Marital Status } \\
\hline Married & 45 & 25.00 \\
\hline Single & 112 & 62.22 \\
\hline Divorced & 08 & 4.44 \\
\hline Widowed & 15 & 8.34 \\
\hline \multicolumn{3}{|l|}{ Household Size } \\
\hline$<5$ & 31 & 17.22 \\
\hline $5-10$ & 129 & 71.67 \\
\hline $11-15$ & 17 & 9.44 \\
\hline$>15$ & 3 & 1.67 \\
\hline Mean & 7 & \\
\hline \multicolumn{3}{|c|}{ Educational Level } \\
\hline Non-Formal & 74 & 41.11 \\
\hline Primary & 36 & 20.00 \\
\hline Secondary & 42 & 23.33 \\
\hline Tertiary & 28 & 15.56 \\
\hline Total & 180 & 100.0 \\
\hline
\end{tabular}

Source: Field Survey, 2016.

According to Adebayo (2001), education has been a limiting factor for most female farmers, and in this study, about $41 \%$ of the female farmers acquired no 
formal education. This may have an implication on the performance of the respondents in terms of rice production. The result further showed that $62.22 \%$ of female rice farmers were married. This finding lends credence to the submission of Bamiro and Aloro (2013) who revealed that married persons constitute the bulk of the persons engaged in rice production, mostly due to its high labour demand. As shown in the table, female farmers in the area had a mean household size of about 7.

\section{Technical Efficiency of Female Farmers}

Technical efficiency entails adopting certain technologies that will maximize farm output with a minimum quantity of inputs (Bamiro, Aloro, 2013). Table 2 showed the Maximum Likelihood Estimates of the production parameters of the respondents. The result revealed that $71.3 \%$ of the variation in rice output was as a result of the technical in-efficiency of the female farmers (gamma $(Y), 0.713$ which was statistically significant at $1 \%$ ). Also, the sigma squared value was statistically significant at the $1 \%$ level, implying a good fit of the model used. The Likelihood ratio test result established the presence of technical in-efficiency in the production of rice by the respondents in the area. Similarly, the result indicated that significant determinants of rice output were farm-size, hired-labour, and fertilizer which were statistically at $1 \%$. However, Family-labour had a significant effect on rice production at a 5\% level. Farm-size had a significant and positive influence on the output of rice by female farmers. This implies that the output of rice increases with an increase in farm-size. The finding of this study supports the submission of (Ayoola et al., 2011) who observed that access to adequate farm-land had a significant and positive effect on rice production, especially of female farmers. The findings of this study have revealed farm size positively impact the farm. This implies small farm holdings are efficiently managed compared to large ones and vice versa. This finding agrees with those of Okezie et al (2012) and Ayalew and Deininger (2013). This can be attributed to the fact that small farm holdings utilise productive resources like labour and fertilizer per unit of land adequately (Tadesse, Krishnamoorthy, 1997; Assuncao, Ghatak, 2003). Moreover, Table 2 indicated that the factors which contributed to the technical in-efficiency of female farmers include education, farming experience, and farmer's access to credit facilities. Access to formal education has been observed by previous researchers as an important factor that influences farmer's efficiency (Adebayo, 2001; Oladeebo, Fajuyigbe, 2007; Onu, Adebayo, 2010; Ahmadu, Erhabor, 2012; Ogunniyi et al., 2012). The result suggests that with improvement in education, the technical efficiency of the farmers will be improved. This finding aligns with those of Nganga et al (2010), Piya et al (2012), and Nosiru et al (2014) who indicated that attainment of education increases awareness of opportunities to increase farm production through adoption of modern technologies.

This study also showed that female farmers tend to be more technically efficient with more years of farming experience. This implies that an increase in farmer's experience invariably increases efficiency by optimally allocating the resources. The more experience a farmer has, the higher the technical efficiency. This result is in line with the findings of Ogunniyi et al. (2012) and Ayinde et al. (2012) who reported that farming experience significantly affects the technical efficiency of farmers. Furthermore, the availability of credit facilities was statistically significant at the $1 \%$ level and had a great influence on the technical efficiency of the farmers. This finding lends credence to the submission of Bamiro and Aloro (2013) who revealed that credit availability positively influences the technical efficiency of rice farmers. In 
the same vein, Kilic et al. (2009), Obare et al. (2010), Anyanwu (2013) and Al-hassan (2012) also revealed that access to credit has a positive impact on-farm efficiency. This is because access to credit enhances farm investments (timely acquisition and use of inputs) and increases the ability to adopt improved technologies that can increase farm productivity (Osei et al., 2013). Furthermore, the findings of this study revealed that the technical efficiency of female farmers ranges between 0.43 and 0.98 with a mean value of 0.84 which implies that on average, female rice-farmers had the capacity of increasing their production by $16 \%$ given the existing technology. This finding agrees with the results of Adebayo et al. (2010) who reported that most local farmers operate below the expected frontier output. Resource use efficiency demands that factors of production attain technical and allocative optimality (Amos, Iheanacho, 2003, Amaza, Anumah, 2003).

Table 2 Maximum Likelihood Estimates of the Parameters of the Stochastic Frontier Production Function for the Respondents

\begin{tabular}{|c|c|c|c|c|}
\hline Variable & Parameter & Coefficient & Standard Error & t-ratio \\
\hline \multicolumn{5}{|l|}{ Production Factors } \\
\hline Constant & $\beta_{0}$ & 1.9464 & 0.7264 & $2.6795 *$ \\
\hline Farm size & $\beta_{1}$ & 1.0520 & 0.4118 & $5.5460 *$ \\
\hline Seed & $\beta_{2}$ & 0.5604 & 0.4013 & 1.3964 \\
\hline Fertilizer & $\beta_{3}$ & 0.0331 & 0.0105 & $3.1574 *$ \\
\hline Hired Labour & $\beta_{4}$ & 0.0498 & 0.0132 & $3.7772 *$ \\
\hline Family Labour & $\beta_{5}$ & 0.0304 & 0.0142 & $2.1385^{* *}$ \\
\hline Herbicide & $\beta_{6}$ & 0.0246 & 0.0630 & 0.3899 \\
\hline \multicolumn{5}{|l|}{ In-efficiency Factors } \\
\hline Age & $a_{1}$ & -0.1914 & 0.2119 & -0.9034 \\
\hline Education & $a_{2}$ & -0.197 & 0.0969 & $-2.0341^{* *}$ \\
\hline Farming Experience & $a_{3}$ & -0.127 & 0.0371 & $-3.4205 *$ \\
\hline House-hold size & $a_{4}$ & 0.0074 & 0.0464 & 0.0159 \\
\hline Extension services & $a_{5}$ & -0.0816 & 0.1813 & -0.4500 \\
\hline Credit facilities & $a_{6}$ & -0.0400 & 0.0150 & $-2.6568 *$ \\
\hline Sigma squared & $\delta^{2}$ & 0.04494 & 0.0051 & $8.8863 *$ \\
\hline Gamma & $\Gamma$ & 0.07130 & 0.0146 & $4.8998 *$ \\
\hline Log-likelihood function & & & 26.3282 & \\
\hline
\end{tabular}

* Significant at $1 \%,{ }^{* *}$ Significant at $5 \%$.

Source: Computer output from Frontier 4-1, 2016.

\section{The Allocative efficiency of Female Farmers}

The concept of allocative efficiency is related to the ability of a firm to choose its input in a cost-minimizing way. It is meant to assess the ability of firms that are technically efficient to produce at the least possible cost. The Maximum Likelihood estimates of the stochastic cost function for female rice farmers in the study area are presented in Table 3. The result showed that gamma ( $Y=0.8556)$ was statistically significant at a $1 \%$ level indicating the existence of inefficiency effects. The sigma value also was significant at the $1 \%$ level, which confirms a good fit of the model and the correctness of the assumption of the composite error term. According to the result in Table 3, the coefficients of all the variables included in the cost function had the expected positive signs. This suggests that there is a positive relationship between the total cost of production and the cost of these variables. In other words, the total cost of production increased with an increase in any of these input costs. The variables identified as having a significant influence on the cost of rice production 
by female farmers include the cost of fertilizer, cost of seeds, cost of transport, and rent on land.

Table 3 revealed that the factors contributing to the allocative in-efficiency of female farmers include education, household size, and access to credits. The result indicated that the education of the female farmers had negative (statistically significant at $1 \%$ level). This shows the critical role education plays in influencing the efficiency of rice farmers. Ogunniyi et al. (2012) equally observed that education represents a significant determinant of the efficiency of rice farmers. The study also showed that household size was another determinant of the allocative efficiency of the female farmers. Its coefficient had a negative sign which implies that the inefficiency of female farmers reduces with an increase in the size of the household. This establishes the fact that most female farmers operate at a subsistence level that relies mostly on family labour for most of the farming activities. The result buttresses the findings of Ayoola et al. (2011) that female farmers often grow small plots of farmland. Also, the report in Table 3 showed that Access to credit facilities was one of the most critical factors influencing the allocative efficiency of female rice farmers in the area. Credit had the expected negative sign and was statistically significant at $1 \%$ level. The result suggests that the farmers' access to credit facilities will improve their efficiency and vice-versa. This result agrees with the finding of Dhehibi and Telleria (2012) and Mohapatra (2013) on the economic efficiency of farmers in Nigeria and other developing nations.

Table 3 Maximum Likelihood Estimates of the Parameters of the Stochastic Frontier Cost Function for the Female Respondents

\begin{tabular}{|l|c|c|c|c|}
\hline Variable & Parameter & Coefficient & Standard Error & t-ratio \\
\hline Production Factors & & & & \\
Constant & $\beta_{0}$ & 2.1225 & 0.1625 & $13.0605^{*}$ \\
Cost of Fertilizer & $\beta_{1}$ & 0.0265 & 0.0035 & $7.6031^{*}$ \\
Cost of Seed & $\beta_{2}$ & 0.4274 & 0.0612 & $6.9826^{*}$ \\
Cost of Transport & $\beta_{3}$ & 0.1715 & 0.0714 & $2.4013^{* *}$ \\
Cost of Labour & $\beta_{4}$ & 0.0587 & 0.3596 & 0.1631 \\
Cost of Herbicides & $\beta_{5}$ & 0.0153 & 0.0432 & 0.3536 \\
Rent on Land & $\beta_{6}$ & 0.0219 & 0.0100 & $2.1997^{* *}$ \\
& & & & \\
In-efficiency Factors & & & & \\
Age & $\mathrm{a}_{1}$ & 0.0780 & 0.6610 & 0.1120 \\
Education & $\mathrm{a}_{2}$ & -0.0372 & 0.0124 & $-2.9921^{*}$ \\
Farming Experience & $\mathrm{a}_{3}$ & 0.6838 & 1.0885 & 0.6282 \\
House-hold size & $\mathrm{a}_{4}$ & -0.0886 & 0.0438 & $-2.0236^{* *}$ \\
Extension services & $\mathrm{a}_{5}$ & -0.4236 & 0.5071 & -0.8353 \\
Credit facilities & $\mathrm{a}_{6}$ & -0.1552 & 0.0220 & $-7.0460^{*}$ \\
Sigma squared & $\delta_{2}$ & 0.4366 & 0.0591 & $7.3935^{*}$ \\
Gamma & $\Gamma$ & 0.8556 & 0.0608 & $14.0665^{*}$ \\
Log-likelihood function & \multicolumn{4}{|l|}{} \\
\hline
\end{tabular}

* Significant at $1 \%, * *$ Significant at $5 \%$.

Source: Computer output from Frontier 4-1, 2016.

\section{Distribution of economic efficiency of female respondents}

Economic or total efficiency is the product of technical and allocative efficiency. Table 4 presents the distribution of the economic efficiency of the respondents. The result showed that only $4.45 \%$ of the female farmers had an Economic Efficiency of $71 \%$ and above. The mean economic efficiency of female farmers was 0.69. The maximum economic efficiency of female farmers was 0.82. The most in-efficient 
(minimum) economic efficiency for the female farmer was 0.27 . This finding implies that the majority of the respondents are relatively efficient in utilising productive resources in the study area.

Table 4 Distribution of Economic Efficiency of Female Respondents

Source: Field Survey, 2016.

\begin{tabular}{|l|c|c|}
\hline Economic Efficiency & Frequency & Percentage (\%) \\
\hline$\leq 0.50$ & 53 & 29.44 \\
$0.51-0.60$ & 72 & 40.00 \\
$0.61-0.70$ & 47 & 26.11 \\
$0.71-0.80$ & 7 & 03.89 \\
$0.81-0.90$ & 1 & 0.56 \\
Total & 180 & 100.00 \\
Minimum & 0.27 & \\
Maximum & 0.82 & \\
Mean & 0.69 & \\
\hline
\end{tabular}

\section{Conclusion}

The study showed the existence of both technical and allocative inefficiencies in the production of rice by the respondents. The research findings showed that farm-size, fertilizer, and hired-labour were statistically significant determinants of rice output of female farmers at a $1 \%$ level. Similarly, the study revealed that Family-labour also significantly affect rice production in the study area. The study further revealed that educational status, farming experience, and access to credit facilities were the socio-economic factors that contributed to the technical in-efficiency of the farmers. The variables identified as having a significant influence on the cost of rice production by female farmers include the cost of fertilizer, cost of seeds, cost of transport, and rent on land. The factors contributing to the allocative in-efficiency of female farmers include education, household size, and access to credits. It was therefore recommended that Government policy should emphasize measures that promote women farmers' access to agricultural resources and services at affordable prices which will contribute to empowering female farmers economically, thereby reducing the gender gap existing among rice-farmers in the country. Also, Farmers should be organized into cluster groups or cooperatives which will aid their ability in terms of securing collateral for accessing credit facilities from banks with which they could acquire better and improved technology for rice production in the rural areas. In conclusion, the scope of this study was limited to female rice farmers who are members of farmers' associations. However, similar studies can be conducted on female farmers who are not members of farmers' associations. Similarly, a longitudinal study can be conducted on the respondents so as to clearly understand factors that influence rice production among female farmers in the study area.

\section{References}

1. Adebayo, A. A., Tukur, A. L. (1999). Climate (Sunshine, Temperature, Evaporation and Relative Humidity) Adamawa State in Map. Department of Geography, Federal University of Technology, Yola, pp. 20-26.

2. Adebayo, E. F, Moses J. D., Olawoye, H. U. (2010). Technical Efficiency of Women Farmers in Adamawa State. Proceedings of the Annual National Conference of Farm Management Association of Nigeria, FAMAN, Adamawa State University Mubi, Nigeria, October 11-14, 2010, pp. 267-272.

3. Adebayo, E. F. (2001). Determinants of Rice Production by Women Farmers in Yola Area of Adamawa State, Nigeria. Yolde Journal, Vol. 3, No. 4, pp. 50-54. 
4. Ahmadu, J., Erhabor, P. O. (2012). Determinants of Technical Efficiency of rice farmers in Taraba State, Nigeria. Nigerian Journal of Agriculture, Food and Environment, Vol. 8, No. 3, pp. 78-84.

5. Aigner, D. J., Lovell, C. A. K., Schimidt, P. (1977). Formulation and Estimation of Stochastic Frontier Function Models. Journal of Econometrics, Vol. 6, pp. 21-37.

6. Akande, T. (2002). Overview of rice economy. Available at www.uk.urep.ch/etp/events/agriculture [18 September 2020].

7. Amaza P. S., Anumah, C. O. (2003). Resource use Efficiency in Maize Production in Askira/Uba Local Government Area of Borno State, Nigeria. Journal of Arid Agriculture, Vol. 13, pp.117-120.

8. Amos, T. T., Iheanacho, A. C. (2003). Comparative Economic Efficiency in Small Scale Poultry Production in Kaduna State, Nigeria. Journal of Arid Agriculture, Vol. 13, pp. 121126.

9. Angya, C. A. (2008). Gender Issues in Agriculture and Rural Development in Nigeria: The Impending Food Crisis. Proceedings of the First National Conference of the Society for Gender in Agriculture and Rural Development, University of Agriculture, Makurdi, Benue State, Nigeria, pp. 10-17.

10.Assuncao, J. J., Ghatak, M. (2003). Can unobserved heterogeneity in farmer ability explain the inverse relationship between farm size and productivity. Economics Letters, Vol. 80, pp. 189-194.

11.Ayinde, O. E, Akanbi, O. E., Omotesho, O.A. (2012). Efficiency Differential of Government and Non-Governmental Assisted Rice Farms: A Case-study of Kwara State, Nigeria. World Rural Observations, Vol. 4, No. 3, pp. 1-13.

12.Ayoola, J. B., Dangbeno, C., Daudu C. K., Mando, A., Kudi, T. M., Amapu, I. Y., Adeosun, J. O., Ezuil, K. S. (2011). Socio-economic Factors Influencing Rice Production among Male and Female Farmers in Northern Guinea Savannah, Nigeria: Lesson for Promoting Gender Equity in action Research. Agriculture and Biology Journal of North America, Vol. 2, No. 6, pp. 1010-1014.

13.Badawi, T. A. (2004). Rice Based Production System for Food Security and Poverty Alleviation in the Near-East and North Africa. Available at http://www.faw.org/rice2004/en/pdf.badawi.pdf [18 September 2020].

14.Bamiro, O. M. Aloro, J. O. (2013). Technical Efficiency in Swamp and Upland Rice Production in Osun State. Journal of Agricultural Science, Vol. 3, No. 1, pp. 31-39.

15. Coelli, T. J. (1995). Recent Development in Frontier Modelling and Efficiency Measurement. Australian Journal of Agricultural Economics, Vol. 39, No. 3, pp. 219-245.

16.Daranola, B. (2005). Government policy and competitiveness of Nigeria rice economy. Paper presented at the workshop on rice policy and food security in Sub-Sahara Africa Organized WARDA Cotonous, Benin.

17.Dhehibi, B., Telleria, R. (2012). Irrigation water use efficiency and farm size in Tunisian Agriculture: a parametric analysis approach. American-Eurasian Journal of Agric. and Environmental Science, Vol. 12, No. 100, pp. 1360-1376.

18.Dia, Y. Z., Dia, R. Z., Dia, W. Z., Vanko, S. (2009). Assessment of Women Labour towards Agricultural Production in Michika Local Government of Adamawa State. Journal of Agricultural Research and Policies, Vol. 4, No. 4, pp. 101-108.

19.Effiong, J. B., ljioma, J. C., Okolo, L. C. (2015). Participation of Women Farmers in Rice Production in Bende Local Government Area, Abia State. International Journal of Agricultural Extension and Rural Development Studies, Vol. 2, No. 2, pp. 1-9.

20.Erenstein, O., Lançon, F., Akande, S. O., Titilola, S. O., Akpokodje, G., Ogundele, O. O. (2003). The Nigerian Rice Economy in A Competitive World: Constraints, Opportunities and Strategic Choices Rice production systems in Nigeria: A survey. pp. 1-95.

21.Fan, S. (1999). Technological Change, Technical and Allocative Efficiency in Chinese Agriculture: The Case of Rice Production in Jiangsu. EPTD Discussion Paper, No. 39.

22.FAO (2013). Global Rice Sector Development. Price Market Monitor. Available at http://agritrade.cta.int/Agriculture/Commodities/Rice/Executive-Brief-Update-2013-Ricesector [18 September 2020]. 
23.Farell, M. J. (1957). The Measurement of Productive Efficiency. Journal of the Royal Statistical Society, Vol. 3, pp. 253-290.

24. Ibrahim, A. A. (2014). Adoption Decision on Rice Production Technologies by Farming Households Under Borno State Agricultural Development Programme, Nigeria. International Journal of Research in Agriculture and Food Sciences, Vol. 2, No. 3, pp. 26-31.

25.Ismaila, U., Gana, A. S., Tswanya, N. M., Dogara, D. (2010). Cereals Production in Nigeria: Problems, Constraints and Opportunities for Betterment. African Journal of Agricultural Research, Vol. 5, No. 12, pp. 1341-1350.

26.Iwuchukwu, J. C., Udegbunam, I. C. (2017). Productivity and Gender/Intra-Household Roles in Rice Production in Awka North Local Government Area, Anambra State, Nigeria. Journal of Agriculture and Ecology Research International, Vol. 11, No. 1, pp. 1-9.

27.Kagbu, J. H., Omokore, D. F., Akpoko, J. G. (2016). Adoption of Recommended Rice Production Practices among Women Rice Farmers in Nasarawa State, Nigeria. Journal of Agricultural Extension, Vol. 20, No. 1, pp. 107-120.

28.Kalirajan, K., Shand, R. (1999). Frontier Production Functions and Technical Efficiency Measures. Journal of Economic Surveys, Vol. 13, pp. 149-172.

29.Kopp, R. J., Smith, V. K. (1980). Frontier production function estimates for stream electric generation: A comparative analysis. Southern Economic Journal, Vol. 47, pp. 1049-1059.

30.Kura, M. U. (2009). Rice Production in Kano State: Current Status and Prospect. Paper Presented at the stakeholders' workshop on Kano State Rice Development Policy, Kano.

31.Mohapatra, R. (2013). Global Technical Efficiency and Variable Returns to Scale: Implication on Paddy Production. International Journal of Advanced Research, Vol. 12, pp. 107-117.

32. Moses, J., Adebayo, E. F. (2007). Efficiency of factors determining rain fed rice production in Ganye Local Government Area, Adamawa State. Journal of Sustainable Development and Environment, Vol. 3, pp. 20-30.

33.Muhammad-Lawal, A., Omotesho, O. A., Falola, A. (2009). Technical Efficiency of Youth Participation in Agriculture: A Case Study of The Youth - In - Agriculture Programme in Ondo State, South Western Nigeria. Nigerian Journal of Agriculture, Food and Environment, Vol. 5, No. 1, pp. 20-26.

34.National Bureau of Statistics (2014). Quarterly Reports. Available at http://www.nigerianstat.gov.ng [18 September 2020].

35. National Population Commission (2006). Population Figures for Nigerian States for 2006 Population and Housing Census. Available at www.npc.org.ng [18 September 2020].

36.Nosiru, O. M. O., Rahji, M. A. Y., Ikpi, A. E., Adenegan, K. O. (2014). Scale efficiency and determinants of productivity of new rice for Africa (Nerica) farmers in Kaduna State, Nigeria. Agrosearch, Vol. 14, No. 2, pp. 113-128.

37. Ogundari, K., Ojo, S. O. (2006). An Examination of Technical, Economic and Allocative Efficiency of Small Farms: The Case Study of Cassava Farmers in Osun State of Nigeria. Journal of Central European Agriculture, Vol. 7, No. 3, pp. 423-432.

38. Ogunniyi, L. T., Adepoju, A. A., Ganiyu, M. O. (2012). A Comparative Analysis of Economic Efficiency between Traditional and Improved Rice Varieties Farmers in Oriade Local Government Area of Osun State. Trends in Agricultural Economics, Asian Network for Scientific Information, pp. 1-13.

39.Okezie, A. C., Ulumna, A. C., Sulaiman, J. (2012). Exploring the Link between Land Fagmentation and Agricultural Productivity. International Journal of Agriculture and Forestry, Vol. 2, No. 1, pp. 30-34.

40.Okoruwa, V. O., Ogundele, O. O. (2008). Technical Efficiency Differentials in Rice Production Technologies in Nigeria. Available at www.csae.ox.ac.uk/conferences/2006EOI-RPI/papers/csae/Okoruwa.pdf [18 September 2020].

41.Oladeebo, J. O., Fajuyigbe, A. A. (2007). Technical Efficiency of Men and Women Upland Rice Farmers in Osun State, Nigeria. Journal of Humanities and Ecology, Vol. 22, No. 2, pp. 93-100.

42.Onu, J. I., Adebayo, E. F. (2010). Resource-use Efficiency in Sole Cotton Production in Economic Adamawa State and Gombe State of Nigeria. African Journal of Business and Research, Vol. 1, No. 2, pp. 167-170. 
43. Osabuohien, E., Okorie, U., Osabohien, R. (2018). Rice Production and Processing in Ogun State, Nigeria: Qualitative Insights from Farmers' Association. In Food Systems Sustainability and Environmental Policies in Modern Economics, Obayelu, E. (Ed.), pp. 188-215.

44.Piya, S., Kiminami, A., Yagi, H. (2012). Comparing the technical efficiency of rice in urban and rural areas: A case study from Nepal. Trends in agricultural Economics, Vol. 5, No. 2, pp. 1-13.

45.Sheikh, T. S. (2006). Technical Efficiency of Rice Production in Bangladesh in a Stochastic Frontier Model. Journal of Business and Economics, Vol. 3, No. 1, pp. 11-34.

46.Tadesse, B., Krishnamoorthy, S. (1997). Technical efficiency in paddy farms of Tamil Nadu: An analysis based on farm size and ecological zone. Agricultural Economics, Vol. 16, No. 3, pp. 185-192.

47.United Nations Development Programmes (2010). Gender and Poverty. Available at http:/www.undp.org \GenderandPovertyReduction.mhtDillman [18 September 2020].

48.Yao, S., Liu, Z. (1998). Determinants of Grain Production and Technical Efficiency in China. Journal of Agricultural Economics, Vol. 46, No. 2, pp. 171-184.

\section{About the authors}

Adewuyi Adekunle Kolawole ( $\mathrm{PhD}$ ) is a senior lecturer at the Department of Agricultural Technology, Federal Polytechnic, Mubi, Adamawa State, Nigeria. His fields of interest are Statistics, Econometrics, and production economics. He has authored several papers and articles published in both local and international journals and conferences. Author can be contacted at kolbetsy@yahoo.com.

Amurtiya Michael holds a PhD in Agricultural Economics from Modibbo Adama University of Technology Yola, Nigeria. His fields of interests are rural livelihoods, Poverty and value chain analysis. He has authored several research papers published in both local and international journals. He has also participated in several local research projects and have served as a reviewer to quite a number of scholarly journal companies. The author can be contacted at michael.amurtiya@mautech.edu.ng. 